\title{
Kaitan Pembelajaran Bahasa Indonesia dengan Lingkungan
}

\author{
Persis Siswandi Tinambunan/18016205 \\ Universitas Negeri Padang-FBS \\ Siswandy01@gmail.com
}

Salah satu masalah lingkungan yang dihadapi Indonesia, yaitu masalah kebersihan. Banyak masyarakat Indonesia yang belum sadar tentang pentingnya kebersihan lingkungan, khususnya tentang membuang sampah pada tempatnya. Kesadaran masyarakat Indonesia untuk membuang sampah pada tempatnya masih tergolong sangat rendah. Masyarakat sering membuang sampah sembarangan, seperti membuang sampah ke sungai, ke jalan, dan tempattempat yang bukan tempat sampah. Hal ini yang membuat lingkungan semakin hari semakin kotor dan tidak sehat. Salah satu masalah kebersihan lingkungan ini terjadi di lingkungan sekolah. Lingkungan sekolah sangat berpengaruh terhadap keberhasilan proses pembelajaran, tetapi siswa banyak yang tidak menyadari hal itu. Padahal jika lingkungan sekolah kotor siswa akan merasa tidak nyaman melakukan kegiatan pembelajaran. Menurut Sukma dan Sihes (2016) proses pembelajaran di sekolah dasar diciptakan dengan suasana yang kondusif dan menyenangkan. Proses pembelajaran adalah proses interaksi peserta didik dan sumber belajar pada suatu lingkungan belajar. Syofiani, Zaim, Ramadhan, dan Agustina (2019) mengatakan pembelajaran yang menyenangkan adalah suasana pembelajaran yang dapat memusatkan perhatian siswa secara penuh saat belajar sehingga curah waktu perhatiannya (time on task) tinggi.

Untuk mengatasi permasalahan kerusakan lingkungan, diperlukan sebuah tindakan yang serius untuk mencegah kerusakan lingkungan yang semakin memburuk. Menurut Nazarenko dan Bergman (dalam Ramadhan et al, 2019), untuk mengatasi ini, guru memainkan peran penting dalam mengajar pendidikan lingkungan dan menumbuhkan kesadaran siswa tentang lingkungan. Ramadhan, Sukma, dan Indriyani (2019) mengatakan peningkatan kesadaran tentang lingkungan dapat diperoleh melalui proses pendidikan. Pendidikan merupakan elemen kunci dalam pencegahan dan resolusi masalah lingkungan. Menurut Ramadhan et.al (2018) Model pembelajaran yang inovatif mampu meningkatkan hasil belajar peserta didik. Oleh sebab itu, pengintegrasian pendidikan lingkungan dalam proses pembelajaran bahasa merupakan sebuah langkah yang tepat dalam mengekspor 
kemampuan siswa sehingga siswa dapat berinovasi dan berkolaborasi dengan lingkungan yang ada disekitar mereka. Sukma (2019) mengatakan bahwa guru hendaknya menyediakan materi yang sesuai dengan kondisi, usia, minat, kebiasaan, maupun lingkungan kehidupan siswa.

Mengingat pentingnya pendidikan lingkungan untuk hidup yang berkelanjutan, maka pendidikan lingkungan harus diterapkan di masyarakat mulai dari usia dini. Setiap sekolah harus bisa memperkenalkan siswa dalam memahami kondisi dan masalah alam saat ini. Hal ini bertujuan untuk meningkatkan kesadaran para siswa untuk lebih peka terhadap kondisi alam saat ini. Sukma, Ramadhan, dan Indriyani (2020) mengatakan peran penting pendidikan lingkungan adalah mengembangkan individu yang memiliki pengetahuan ilmiah tentang masalah lingkungan dan kepedulian lingkungan yang tinggi. Pemanfaatan lingkungan merupakan salah satu media pembelajaran yang baik untuk diterapkan dalam proses belajar, karena dapat menumbuhkan minat dan semangat peserta didik. Hal ini dapat diterapkan dalam mata pelajaran bahasa Indonesia. Karena siswa bisa mengamati apa yang ada di dalam lingkungan dan menjadikan apa yang siswa lihat sebagai salah satu sumber inspirasi untuk membuat suatu karya sastra. Sukma (2012) mengatakan pembelajaran sastra ditujukan untuk meningkatkan kemampuan siswa dalam menikmati, menghayati, dan memahami karya sastra serta mengambil hikmat atas nilai-nilai luhur yang terselubung di dalamnya. Wasillah, Ramadhan, dan Noveria (2016) mengatakan pembelajaran bahasa juga dapat meningkatkan keterampilan berbahasa, memperluas wawasan, dan mendorong siswa untuk memiliki kemampuan bersastra yang komunikatif. Selain itu, berpotensi membantu generasi penerus mengelola kehidupan dan membangun masa depan yang sejahtera. Pendidikan lingkungan harus dirancang untuk berkontribusi pada pengembangan kognitif, emosional, linguistik dan psikomotor siswa, dan memungkinkan mereka untuk mengembangkan sikap positif terhadap lingkungan.

Angin, Ramadhan, dan Agustina (2015) mengatakan menggunakan materi lingkungan membuat siswa lebih peka terhadap lingkungannya karena dapat menyajikan hasil pengamatannya. Sikap dan motivasi belajar yang tinggi pada siswa diharapkan bisa membantu dalam pencapaian hasil belajar yang maksimal. Zulhafizh, Atmazaki, dan Ramadhan (2013) mengatakan bahwa meningkatnya sikap dan motivasi belajar siswa pada aktivitas belajar sangat diharapkan agar hasil belajar siswa juga meningkat. Usaha untuk mengetahui tingkat peran sikap dan motivasi belajar terhadap hasil belajar, khususnya pada pelajaran bahasa Indonesia, perlu dilakukan pengamatan dan analisis terhadap sikap dan 
motivasi belajar tersebut. Diketahuinya sikap dan motivasi belajar siswa, membantu para guru atau pihak sekolah dalam merumuskan berbagai strategi yang patut direncanakan dalam mengembangkan kegiatan belajar mengajar, terutama pada pelajaran bahasa Indonesia.

Berdasarkan permasalahan yang telah dijabarkan di atas penulis telah melakukan penelitian mengenai “Kaitan Pembelajaran Bahasa Indonesia dengan Lingkungan” penulis telah menyebarkan angket tersebut kepada mahasiswa dari berbagai jurusan, semester, dan universitas. Sebanyak 44 responden ikut serta dalam pengisian angket tersebut, seperti dari Universitas Negeri Semarang, Universitas Hasanuddin Makassar, Universitas Pembangunan Panca Budi, Universitas Malikussaleh, Universitas Negeri Medan, Universitas Islam Sumatera Utara, IAIN Bukittinggi, IAKN Tarutung, dan Universitas Negeri Padang yang wajib mencantumkan jenis kelamin dan juga pekerjaan. Dari jumlah keseluruhan responden yang ikut serta mengisi angket tersebut, ternyata perempuan jauh lebih dominan dibandingkan laki-laki dimana responden perempuan mencapai 37 orang dengan persentase (84,1\%), dan responden laki-laki mencapai 7 orang dengan persentase (15,9\%). Penelitian ini dilakukan dengan menggunakan google form, penulis memberikan 10 pernyataan yang wajib diisi oleh responden.

Hasil yang didapat dari penelitian ini adalah sebagai berikut. Pernyataan pada butir pertama, mengenai pentingnya materi lingkungan untuk dipelajari, yang menyatakan setuju (61,4\%), sangat setuju (38,6\%), kurang setuju dan tidak setuju (0\%). Pernyataan pada butir kedua, mengenai materi lingkungan dapat memudahkan siswa dalam memahami materi bahasa Indonesia, yang menyatakan setuju (68,2\%), sangat setuju (25\%), kurang setuju $(6,8 \%)$ dan tidak setuju (0\%). Pernyataan pada butir ketiga, mengenai materi lingkungan sangat erat kaitannya dengan kehidupan sehari-hari, yang menyatakan sangat setuju (56,8\%), setuju (43,2\%), kurang setuju dan tidak setuju (0\%). Pernyataan pada butir keempat, mengenai pembelajaran tentang materi lingkungan secara langsung atau tidak langsung dapat membentuk kepribadian mandiri pada siswa, mengembangkan pola pikir, bertindak, serta berperilaku sehat secara fisik dan mental, yang menyatakan setuju $(61,4 \%)$, sangat setuju (34,1\%), tidak setuju (4,5\%), dan kurang setuju (0\%). Pernyataan pada butir kelima, dengan mengintegrasikan pendidikan lingkungan ke dalam kelas, guru dapat meningkatkan minat siswa terhadap permasalahan kontemporer yang mungkin langsung mempengaruhi masa depan siswa, yang menyatakan setuju (61,4\%), sangat setuju $(34,1 \%)$, kurang setuju (4,5\%), dan tidak setuju (0\%). Pernyataan pada butir keenam, lingkungan dapat dijadikan sebagai media dalam pembelajaran bahasa Indonesia, yang menyatakan setuju (54,5\%), 
sangat setuju (43,2\%), kurang setuju (2,3\%), dan tidak setuju (0\%). Pernyataan pada butir ketujuh, materi lingkungan berkaitan dengan pembelajaran bahasa Indonesia serta berkaitan dengan pelajaran Geografi, yang menyatakan setuju (70,5\%), sangat setuju (18,2\%), kurang setuju (9,1\%), dan tidak setuju (2,3\%). Pernyataan pada butir kedelapan, upaya-upaya pelestarian lingkungan dapat dilakukan melalui teks-teks bacaan dalam pembelajaran bahasa Indonesia, yang menyatakan setuju (61,4\%), sangat setuju (34,1\%), kurang setuju (4,5\%) dan tidak setuju (0\%). Pernyataan pada butir kesembilan, memberikan materi lingkungan dalam pembelajaran bahasa Indonesia merupakan salah satu upaya membangun kecerdasan ekologis, yang menyatakan setuju (72,7\%), sangat setuju (23,3\%), kurang setuju dan tidak setuju (0\%). Pernyataan pada butir kesepuluh, guru memiliki kontribusi penting dalam mengenalkan pengetahuan lingkungan melalui pembelajaran di kelas, yang menyatakan setuju (52,3\%), sangat setuju (45,5\%), kurang setuju (2,3\%) dan tidak setuju $(0 \%)$.

Dari hasil pengisian angket yang telah penulis lakukan dapat disimpulkan bahwa banyak mahasiswa atau calon guru yang setuju bahkan sangat setuju untuk membuat materi ajar bahasa Indonesia bertema lingkungan. Karena dengan menggunakan tema lingkungan dalam pembelajaran bahasa Indonesia dapat memperkenalkan kepada siswa tentang lingkungan, sehingga diharapkan dapat meningkatkan rasa peduli siswa terhadap lingkungan, khususnya terhadap kebersihan lingkungannya. 


\section{Daftar Rujukan}

Sukma, E., Ramadhan, S., Indriyani, V. (2020). Integration Of Environmental Education In Elementary Schools. Journal of Physics: Conference Series.1481(1): 1-2

Sukma, Elfia, Sihes, Ahmad Johari. (2016). Kompetensi Kognitif Pembelajaran Apresiasi Sastra Di Sekolah Dasar. Jurnal Gramatika. 1(2); 13

Sukma, E. (2012). Pembelajaran Sastra yang Integratif Berbasis Kompetensi. International Conference on Languages and Arts, 432-436.

Sukma, E. (2019). Problem in oral language teaching in primary school. Seventh international conference on languages and arts (ICLA 2018). Atlantis press.

Ramadhan, S., Sukma, E., \& Indriyani, V. (2019). Environmental education and disaster mitigation through language learning. IOP Conference Series: Earth and Environmental Science, (314. ); 1-9

Ramadhan, S., Asri, Y., \& Indriyani, V. (2018). Learning Module Design Writing Argumentative Text Based Problem-Based Learning. In Advances in Social Science: Education and Humanities Research (Vol. 263, pp. 194-200).

Wasilah, Tri, Ramadhan, S., Noveria, Ena. (2016). Pengaruh Model Pembelajaran Kooperatif Tipe Think Pair Share terhadap Keterampilan Menulis Naskah Drama Satu Babak Siswa Kelas VIII SMP Negeri 30 Padang. Jurnal Pendidikan Bahasa dan Sastra Indonesia. 5(1); 810.

Angin, Toras Barita Bayo, Ramadhan S., Agustina. (2015). Berbasis Pendekatan Kontekstual Pada Menulis Iklan Di Kelas VIII SMP 2 Padangsidimpuan Sumatera Utara. Jurnal Bahasa, Sastra, dan Pembelajaran. 3(1); 27-31.

Zulhafizh, Atmazaki, S., Ramadhan. (2013). Kontribusi Sikap dan Motivasi Belajar Siswa terhadap Hasil Belajar Bahasa Indonesia. Bahasa Sastra dan Pembelajaran. 1 (2).

Syofiani, M., Zaim, S., Ramadhan, A., Agustina (2019). Peningkatan Keterampilan Berbahasa Siswa Melalui Pemanfaatan Media Teka-teki Silang: Menciptakan Kelas yang Menyenangkan. Ta'dib, 21 (2); 87-89.

Nazarenko, A.V. and Kolesnik, A.I. (2018). Raising environmental awareness of future teachers International Journal of Instruction 11(3) 63-76 